\title{
New records and migration strategy of Anax ephippiger (Burmeister, 1839) (Odonata, Aeshnidae) in the territory of the Russian Federation
}

\author{
Находки и характер пребывания Аnax epbippiger \\ (Burmeister, 1839) (Odonata, Aeshnidae) \\ на территории Российской Федерации
}

\author{
O.E. Kosterin*, S.N. Borisov** \\ О.Э. Костерин*, С.Н. Борисов ${ }^{* *}$
}

\footnotetext{
* Institute of Cytology and Genetics SB RAS, Acad. Lavrentyev Ave. 10, Novosibirsk 630090 Russia; Novosibirsk State University, Pirogova Str. 2, Novosibirsk630090 Russia. E-mail: kosterin@bionet.nsc.ru.

* Институт цитологии и генетики СО РАН, пр. Акад. Лаврентьева 10, Новосибирск 630090 Россия; Новосибирский Государственный Университет, ул. Пирогова 2, Новосибирск 630090 Россия.

** Institute of Systematics and Ecology of Animals, Russian Academy of Sciences, Siberian Branch, Frunze Str. 11, Novosibirsk 630091 Russia. E-mail: borisov-s-n@yandex.ru.

** Институт систематики и экологии животных СО РАН, ул. Фрунзе 11, Новосибирск 630091 Россия.
}

Key words: Anax ephippiger, new findings, migrations, the Western Caucasus, Black Sea coast, Russia, Abkhazia.

Ключевые слова: Anax ephippiger, новые находки, миграции, Западный Кавказ, Черноморское побережье, Россия, Абхазия.

Abstract. New records and observations of a migratory dragonfly Anax ephippiger in Russia and the first record in Abkhazia are provided. Due to a peculiar migratory life strategy these dragonflies inhabit the Caucasus only in the warm season.

Резюме. Приводятся новые находки и наблюдения мигрирующего вида стрекоз Anax ephippiger в России и первая находка в Абхазии. Благодаря своеобразной миграционной жизненной стратегии эти стрекозы обитают на Кавказе только в тёплый период года.

\section{Introduction}

Anax ephippiger (Burmeister, 1839) (Fig. 1) is famous for its migratory life history [Corbet 1999; Dumont, Desmet, 1990; Dumont, 2014; Lambret, Boudot, 2013; Kalkman, Monnerat, 2015]. The core of its range is Africa and SW Asia from where vagrant individuals invade Europe, Central and East Asia, reaching Iceland in the north, China, Japan and Thailand in the east and crossing the Atlantic Ocean to reach the Carribean region and even Brazil [Kalkman, Monnerat, 2015; Pierce, 2017]. European records are thought to be mostly associated with African or SW Asian vagrants, with only very limited breeding sometimes occurring [Kalkman, Monnerat, 2015]. The eastern limit of the species' range in Europe is shown by Kalkman and Monnerat [2015] as roughly corresponding with the former U.S.S.R. border but including parts of the Ukraine and Caucasus. At the same time their dot map shows only three points in the part of the Caucasus in Russian Federation. This looked as a bias of insufficient knowledge rather than the actual situation, as the Caucasus is available as a crossroad for migrations from both Africa and SW Asia.

A. ephippiger has been so far reposted only from five localities in the territory of Russian Federation, as listed below. The aim of this work was to reveal more cases of occurrence of this species in Russia and their circumstances.

\section{Materials and Methods}

The work is based on two sources of information:

(i) the collection of the Institute of Systematics and Ecology of Animals of the Siberian Branch of the Russian Academy of Sciences, Novosibirsk (ISEA), including stored but so far untreated materials, and

(ii) the authors' personal observations and collections. The first author visited the Black Sea coast of the western Caucasus in mid-summer 2015, 2016 and 2017; the second author explored the Caucasian region more broadly in 1998 and 2017.

The records of $A$. ephippiger in the Russian part of the Caucasus in general and Abrau Peninsula in particular are shown on the maps of Figs 1 and 2, respectively. Fig. 1 also shows an unpublished record from the adjacent locality of Abkhazia. These figures were produced using the MapCreator 3 software (www.primap.com). The locality numbers correspond to those in the lists below. Geographical coordinates were retrieved from Google 


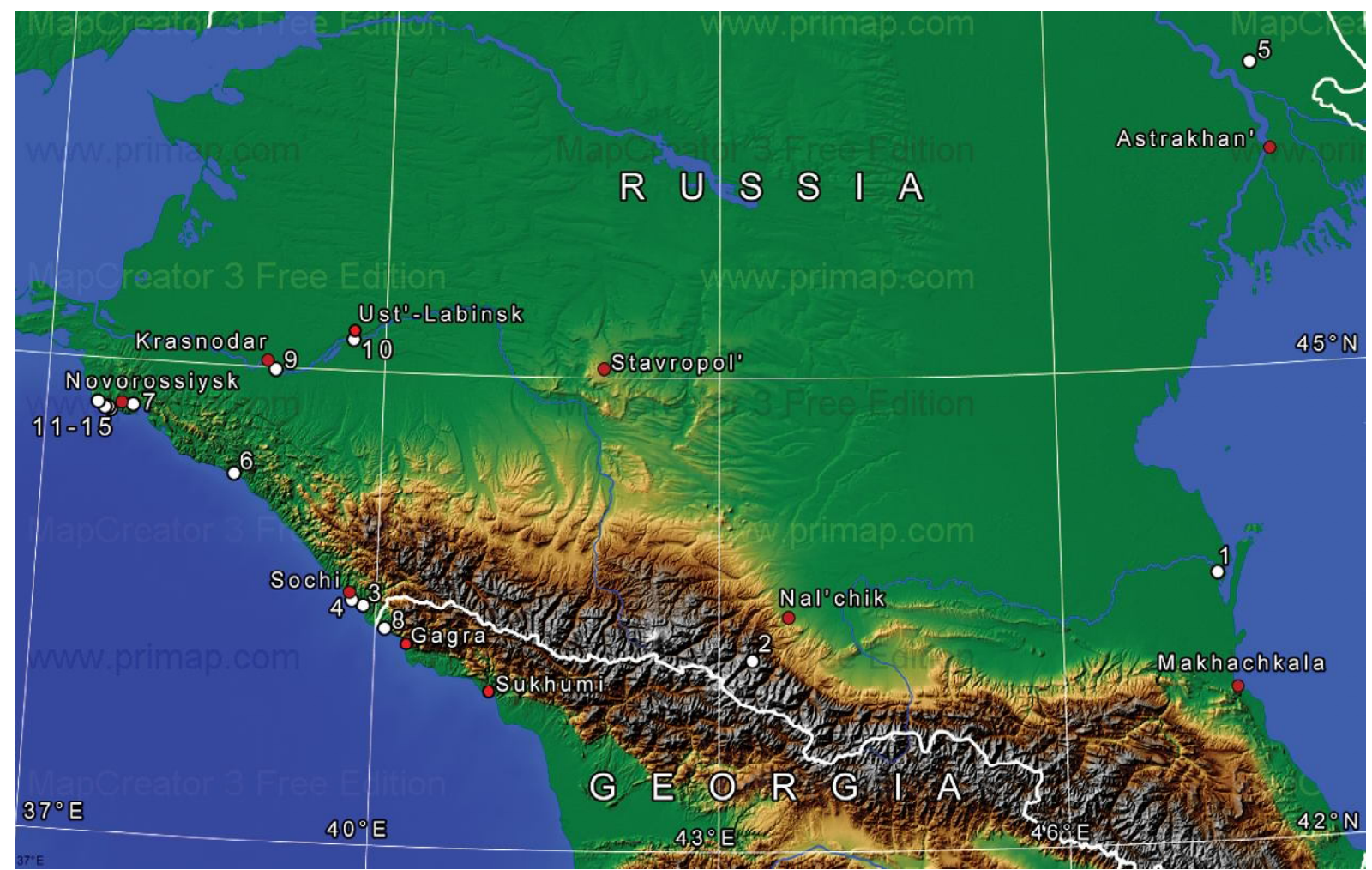

Fig. 1. Localities where Anax epbippiger was found in Russia. For explanation of locality numbers see the text. Рис. 1. Места находок Anax ephippiger в России. Номера цокалитетов соответствуют таковым в тексте.

Earth. The photos of Figs 3 and 4 were taken in nature by the first author.

\section{List of published reports of Anax ephippiger from Russian Federation territory}

1. [Bartenev, 1921]: Stavropol'skiy Kray Province, the Kuma River lower reaches, 19 collected by Vinokurov. (Note that referring to this record, Skvortsov [2010] provided a wrong locality Zimnyaya Stavka (also mentioned by Bartenev with respect to other species). This Bartenev's record of $A$. ephippiger was also referenced by Artobolevskij [1929] as being from 'the steppen Daghestan'.

2. [Skvortsov, 2010]: Kabardino-Balkaria, Bezengi.

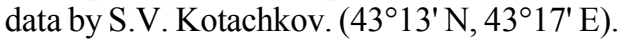

3. [Skvortsov, 2010]: Krasnodarskiy Kray, Sochi District, Khosta, data by S.V. Kotachkov. (43ํำ $31^{\prime}$, 3953' E).

4. [Skvortsov, 2010]: Krasnodarskiy Kray, Sochi District, Matsesta, data by S.V. Kotachkov. (433' N, $\left.39^{\circ} 47^{\prime} \mathrm{E}\right)$

5. [Onishko, 2014]: Astrakhan' Province, Krasnoyarka District, Dosang settlement environs, data by V.V. Onishko $\left(46.923708^{\circ} \mathrm{N}, 47.903106^{\circ} \mathrm{E}\right.$; no date, the excessive 'preciseness' of coordinates as in the cited source).

\section{New material:}

6. Krasnodarskiy Kray, Dzhubga Town, a sea coast, $44^{\circ} 19^{\prime}$ N, $38^{\circ} 42^{\prime} \mathrm{E}, 17$. VIII.1988, 1 \% (collector unknown) (ISEA).

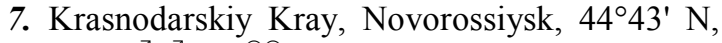
$37^{\circ} 46^{\prime} \mathrm{E}, 4 \sigma^{\top} \sigma^{\top}, 10$ 우 (collector and date unknown) (ISEA).

8. Abkhazia, Gagra District, Gantiadi settlement, $43^{\circ} 23^{\prime}$ N, 4005' E, 31.VIII.1970, 2o+, Violovich leg. (ISEA).

9. Krasnodar, $44^{\circ} 59^{\prime} 7^{\prime \prime} \mathrm{N}, 39^{\circ} 01^{\prime} 21^{\prime \prime} \mathrm{E}, 20 \mathrm{~m}$ a.s.1., 5 , 7.IX.1988, $3 \sigma^{7} \sigma^{7}, 1$, , S.N. Borisov leg.

10. $50 \mathrm{~km}$ E of Krasnodar, Ust'-Labinsk, $45^{\circ} 12^{\prime} 00^{\prime \prime} \mathrm{N}$, $39^{\circ} 42^{\prime} 08^{\prime \prime}$ E, 30 m a.s.1., 30.VIII.1988, several individuals seen, S.N. Borisov.

11. Abrau Peninsula, WNW slope facing, $300 \mathrm{~m} \mathrm{E}$ of Dyurso village, a road through hornbeam forest, $44^{\circ} 40^{\prime} 47^{\prime \prime} \mathrm{N}, 37^{\circ} 33^{\prime} 54^{\prime \prime}$ E, 53 m a.s.1., 22.VII.2017, 1 우, numerous individuals seen, 1 photographed (Fig. 3b), O.E. Kosterin.

12. Abrau Peninsula, $\mathrm{S}$ slope $400 \mathrm{~m} \mathrm{~W}$ of Dyurso village, roadside, $44^{\circ} 40^{\prime} 51^{\prime \prime} \mathrm{N}, 37^{\circ} 33^{\prime} 24^{\prime \prime} \mathrm{E}, 72 \mathrm{~m}$ a.s.l., 20.VII.2017, 3 individuals seen, 1 photographed (Fig. 3a); 21.VII.2017, 3 individuals seen, O.E. Kosterin.

13. Abrau Peninsula, SW slope with sparse juniper/ oak/hornbean stand between Dyurso village and Mokraya Shchel' valley, 4441' N, 37³2' E, 90$120 \mathrm{~m}$ a.s.1., 21.VII.2017, numerous individuals seen, O.E. Kosterin. 
14. Abrau Peninsula, road at a SE slope of the

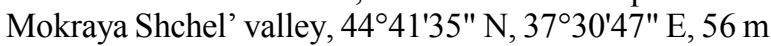
a.s.1., 21.VII.2017, numerous individuals seen, O.E. Kosterin.

15. Abrau Peninsula, road going through hornbeam forest $1 \mathrm{~km} \mathrm{NW}$ of Malyy Utrish village, $44^{\circ} 43^{\prime} \mathrm{N}$, $37^{\circ} 27^{\prime} \mathrm{E}, 36 \mathrm{~m}$ a.s.1., 23.VII.2017, numerous individuals seen, 2 males photographed (Fig. 3c-d), O.E. Kosterin.

\section{Observations}

1. All individuals of $A$. ephippiger collected and observed by the second author (Borisov) in 1988, 5, 9.IX.1988 at Krasnodar (loc. 9) and on 30.VIII.1988 at Ust'-Labinsk (loc. 10), were immature. They were startled from trees and bushes along a ground road or at orchards and flew away, no soaring ones were seen. They were startled from trees and bushes along a ground road or at orchards and flew away, no soaring ones were seen. No water bodies were present nearby.

2 . The species was specially sought for but not found by the second author (Borisov) during his trip to the western Caucasus in May 2017 with the following route: Pyatigorsk (2-6.V.2017), Divnomorsk near Gelendzhik (8-9.V.2017), Novorossiysk (10.V.2017), Anapa (12-13.V.2017), Slavyansk-na-Kubani (1417.V.2017).

3. The first author (Kosterin) found A. ephippiger in mass quantities in Abrau Peninsula between Anapa and Novorossiysk at the stretch of the Black Sea coast from Dyurso village to Malyi Utrish village examined on 20-24.VII.2017.
From the night 19/20.VII.2017 to the evening 20.VII.2017 the coast was struck by a furious (up to $25 \mathrm{~m} /$ s) storm (bora) which followed several days of previous heat (up to $37^{\circ} \mathrm{C}$ ) and came from the north as formed behind the main range of the Caucasus (rather low in its western part). The first author arrived to the coast at the end of the day of 20.VII.2017, immediately after the storm had finished. In the dusk (18:53) he startled three immature individuals of $A$. ephippiger from tall herbs aside a road going through dense oak-hornbeam forest on a SE coastal slope facing Dyurso village (loc. 12). The dragonflies (Fig. 3a) perched very close to each other, maybe within $1 \mathrm{~m}$, on neighbouring stems in a sort of shelter formed by a forest and a bluff at a sharp turn of the road. Next morning, on 21.VII.2017, two individuals were startled from exactly the same place, but none in the evening.

During the day 21.VII.2017, small aggregations of several flying individuals of $A$. ephippiger, were permanently observed all along the road going parallel to the coast, at its examined stretch between Dyurso village and Mokraya Shchel' valley. Besides, two points of concentration of hundreds of individuals were found. One was at a SWS mountain slope covered by juniper/ oak/hornbeam open stand; it occupied quite a large area approximately (loc. 13). The other was at a road at SE slope of the Mokraya Shchel' valley (loc. 14). In these large aggregations, part of individuals swarmed in the air while others perched low at the bases of grass and herbs near trees or bushes but very rarely on their branches, with an intensive turnover observed between the flying and resting individuals. All individuals were immature (still no blue colour) and were very cautious.

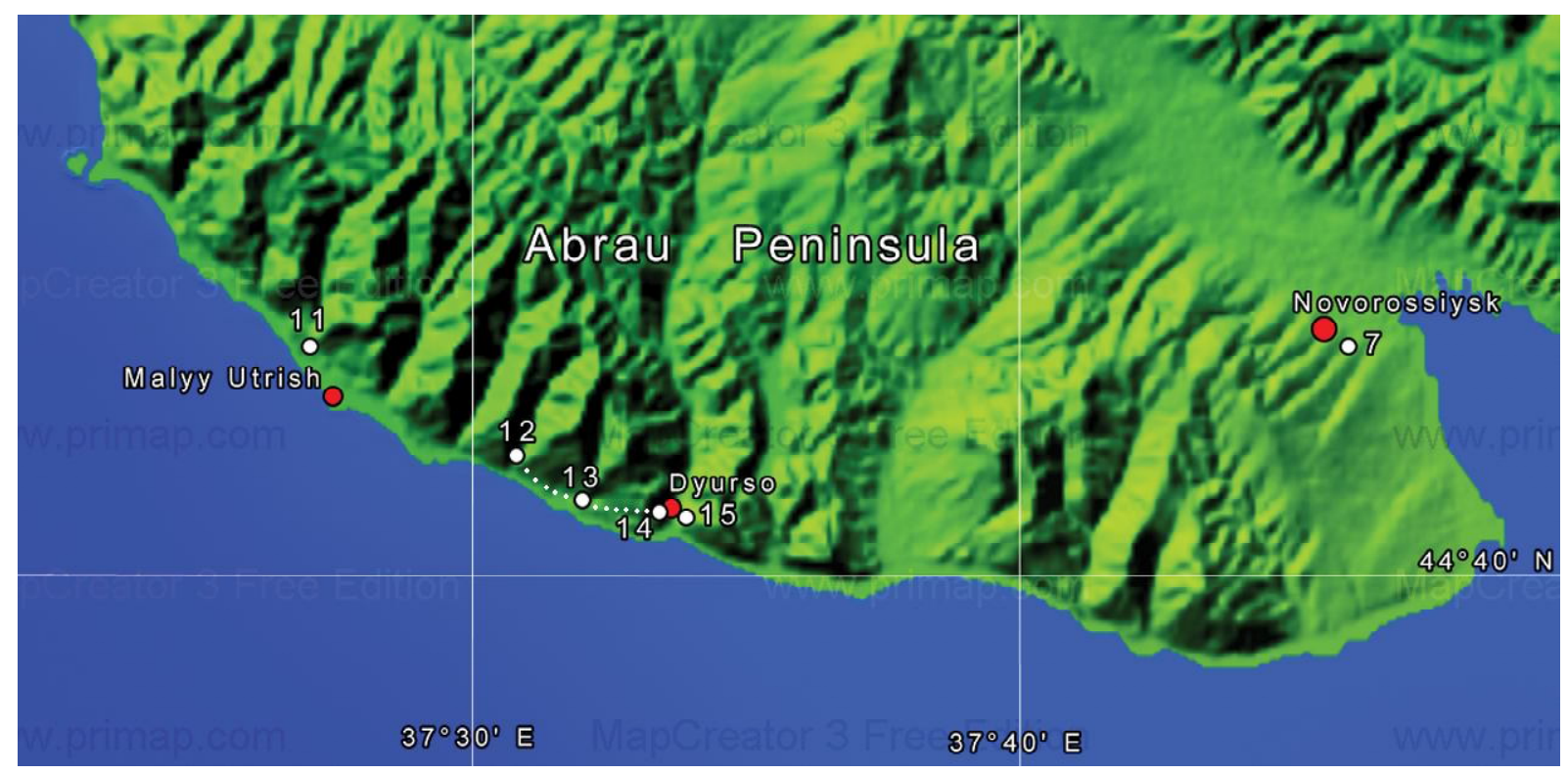

Fig. 2. Localities where Anax ephippiger was found in Abrau Peninsula. For explanation of locality numbers see the text. Pointed line refers to the route along which the species was observed continuously.

Pис. 2 Места находок Anax ephippiger на п-ове Абрау. Номера мокалитетов соответствуют таковым в тексте. На маршруте между кокалитетами 10 и 12 вид встречался постоянно (цепь белых точек). 

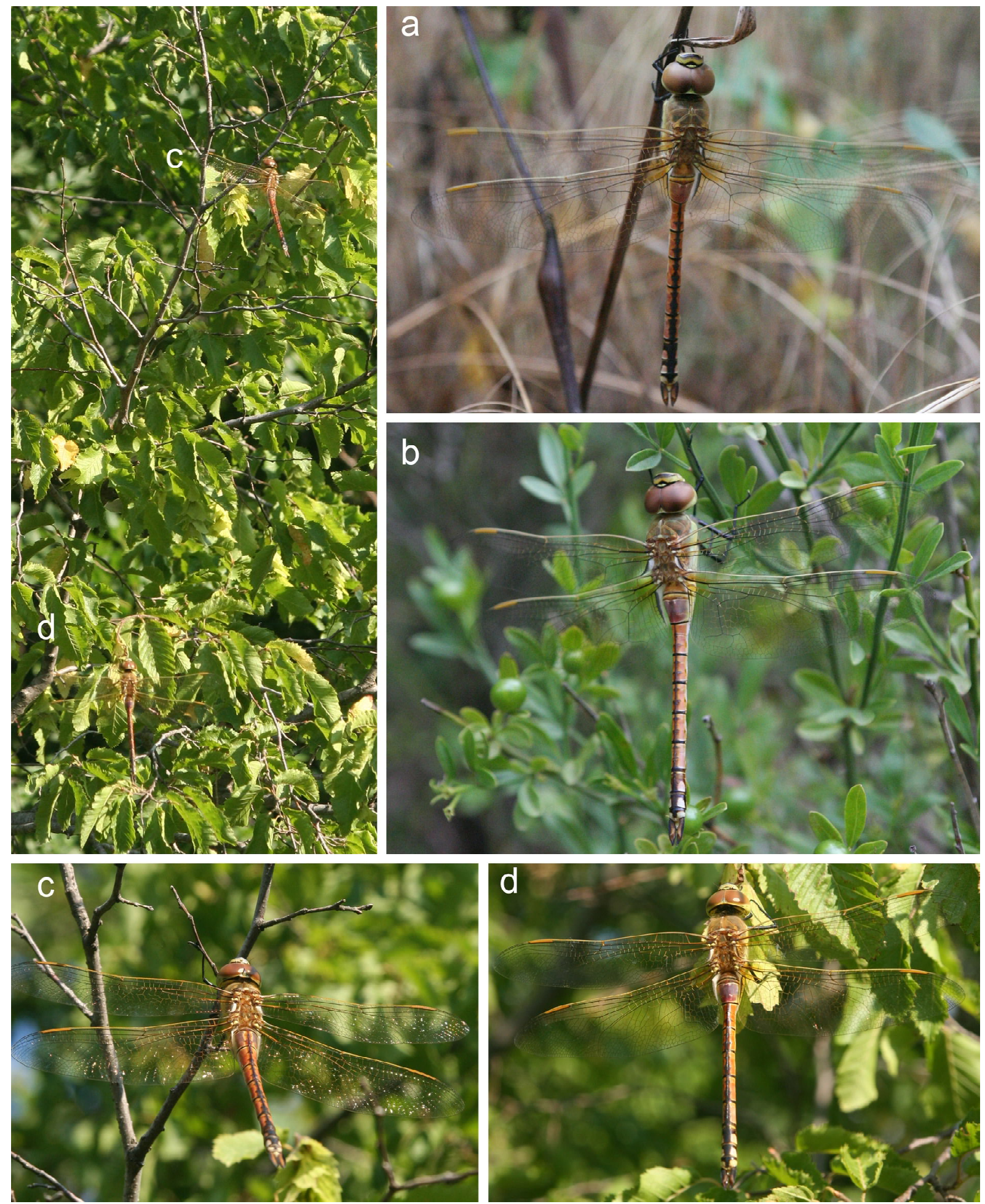

Fig. 3. Perching immature individuals of Anax ephippiger : a - a male at a roadside on S slope $400 \mathrm{~m} \mathrm{~W}$ of Dyurso village, 20.VII.2017; b - a male at a forest road on WSW slope $300 \mathrm{~m}$ E of the Dyurso village, 22 VII.2017; c, d - a female and male $1 \mathrm{~km} \mathrm{NW}$ of Malyy Utrish village, 23.VII.2017.

Рис. 3. Молодые особи Anax ephippiger: а - самец у дороги на южном склоне 400 м 3 с. Аюрсо, 20.VII.2017; b - самец на месной дороге на ВЮВ скмоне 300 м В с. Аюрсо, 22 VII.2017; с, d - самка и самец 1 км СВ с. Мамый Утриш, 23.VII.2017. 
In two subsequent days, two more such congregations were observed. One was found in the morning $(7: 32-7: 40)$ of 22 .VII.2017 at a road going through hornbeam forest on a WNW slope facing Dyurso village (Fig. 3b) (loc. 11); here 1 male was collected. The other was found in the morning (7:42-7:50) of 23.VII.2017 at a road going through hornbeam forest $1 \mathrm{~km} \mathrm{NW}$ of Malyy Utrish village (here most individuals rested on hornbeam branches rather than grass (Fig. 2c-d) (loc. 15). Interestingly, not a single individual of $A$. ephippiger was found there next morning.

4. It should be noted that $A$. ephippiger was not found in Abrau Peninsula in July 2015 and 2016 [Kosterin, Solovyev, 2017].

5. It is noteworthy that on 20-21.VII.2017 individuals of another well-known migrant, Pantala flavescens (Fanricius, 1798), were observed together with A. ephippiger, although not in great numbers (Fig. 4). This species was registered in this area in July 2016 but not 2015 [Kosterin, Soloviev, 2017].

\section{Discussion}

At present $A$. ephippiger is known in Russia mosty from the Caucasus and there is one, the northernmost, record from the Astrakhan' Province. It can be found in other regions, as it has been reported from much more northerly territories of both Europe and Asia [Borisov, 2011; Kalkman, Monnerat, 2015].

The above data suggest that in the Caucasus this species is still known only in later summer and autumn (20 VII - 7 September). It is noteworthy that all collected and/or observed individuals were immature. Those found at Krasnodar and Ust'-Labinsk were subteneral, not more than 1-2 days old, and should have developed in some water bodies nearby. Hence all these dragonflies were of the summer brood, that is progeny of immigrants from the south. This kind of life history is known for A. ephippiger both in Europe [Kalkman, Monnerat, 2015] and Central Asia [Borisov, 2011]. The dragonflies arriving from the tropical and subtropical parts of the range to the southren temperate zone breed successfully. The fast preimaginal development taking fom 70 to 120 days [Bernard, Musial, 1995; Vonwil, Wildermuth, 1990; Lambret, Boudot, 2013] allows adult emergence in late summer to early autumn, that is exactly what we evidenced in the Caucasus.

The mass appearance of $A$. ephippiger observed in Abrau Peninsula is most interesting. No doubt, so numerous individuals arrived to Abrau Peninsula from behind the Caucasus in the north, as following the strong storm. It is known that in tropics, «migrating swarms travel with rain bearing winds (seasonal monsoon fronts), which allow the species to use temporary flooded depressions to breed» [Corbet, 1999; Günter, 2005; Kalkman, Monnerat, 2015: 171]. The same is known for another migratin species, $P$. flavescens. Symptomatically, it was also observed along with A. ephippiger in Abrau Peninsula, although much fewer in num-
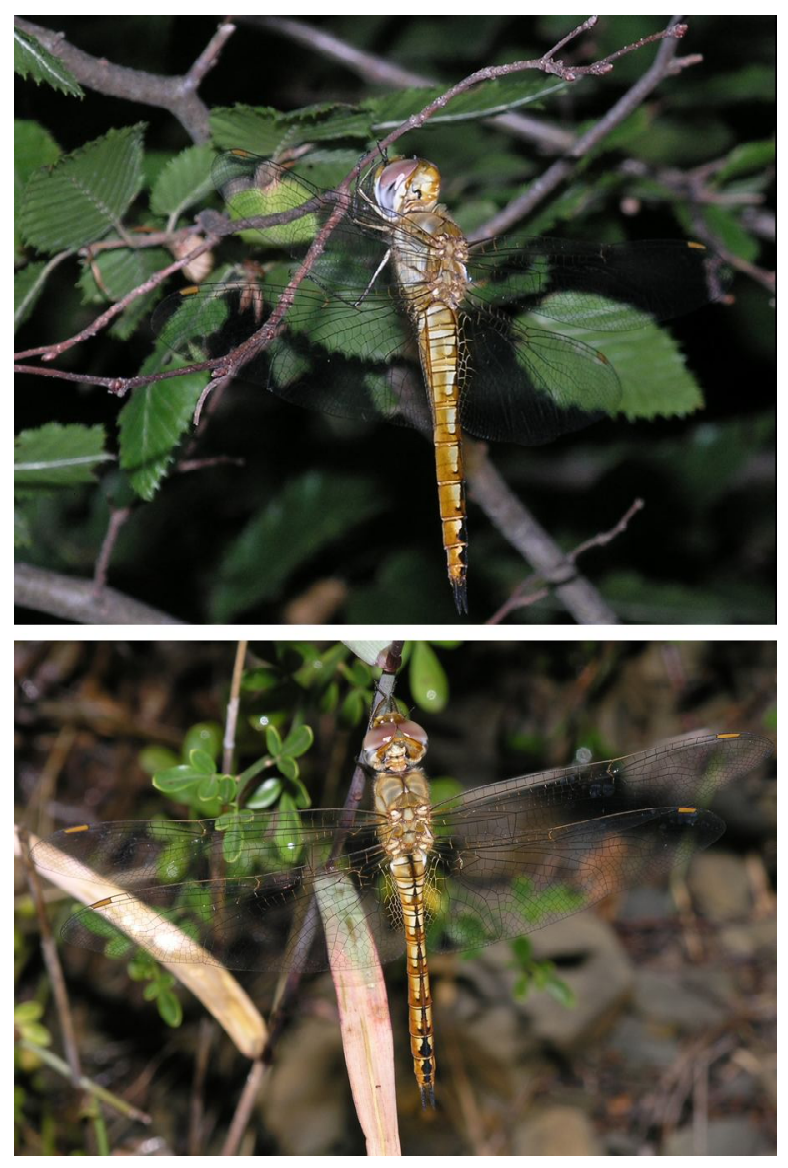

Fig. 4. Females of Pantala flavescens resting in the evening at oak-hornbeam forest margin at the Sukhaya Shchel' Valley $2.3 \mathrm{~km} \mathrm{~W}$ of of Dyurso village, 20.VII.2017.

Рис. 4. Самки Pantala flavescens на опушке Аубовограбового меса в Аолине Сухая Щель 2,3 км 3 с. Аюрсо вечером 20.VII.2017.

ber. So, synoptic processes seem to have similar effect to migrating species of dragonflies [Corbet, 1984, 1999]. This habit of following storms seems to remain in migratory dragonflies at temporary latitudes. Thus, swarms of $A$. ephippiger were observed moving in the southern direction at the Black Sea Coast of Bulgaria in late September / early October 2004 when cold aerial fronts. These dragonflies were presumed to have developed in the western Black Sea region and were forced to migrate to the south by atmospheric processes [Günter, 2005]. A similar situation was observed by the second author at Chokpak Pass in Western Tian Shan. There, intensity of autumn migrations of dragonflies dramatically increases with arriving of cold aerial fronts [Borisov, 2010, 2015]. In North America, a correlation was revealed of the autumn migrations of Anax junius (Drury, 1773) with weather deterioration, that is with coolings and rains. A trend was even observed that whether amelioration (warming or wind cessation) the intensity of migrations decreases or they cease completely [Russel et al., 1998; Wikelski et al., 2006; May, Matthews, 2008; May, 2013]. 
Hence it can be supposed that the congregations of A. ephippiger observed in Abrau Peninsula were expression of their migratory activity, that is formation of swarms before their migration to the south. The autumn southwards migrations of this species in the Black Sea region were reported by Günter [2005]. Marinov [2001] also supposed that there is a regular route of autumn migrations of this species along the Black Sea coast. Our Central Asian data suggest that A. ephippiger directionally migrates to the south in autumn [Borisov, 2015]. In the Mediterranean, the winter development of the larvae of $A$. ephippiger may occur only in the southernmost regions: it was reported from the Atlantic coast of Morocco and, in warm winters, in Spain and southern France [Belle, 1984; Faton, 2003; Lambret, Boudot, 2013].

The breeding sites of the dragonflies observed in Abrau Peninsula cannot be inferred with certainty but they should be in the same region. Most probably these were «limans», the vast brackish river estuaries at the flat Black and Azov sea shores in the flat westernmost territories of Krasnodarskiy Kray: «as might be expected for a species living mainly in seasonal waters, the larvae tolerate the high salinity and many reproduction sites in the Mediterranean are found in brackish coastal wetlands» [Kalkman, Monnerat, 2015: 171].

Hence, the mode of presence of $A$. ephippiger in the Caucasus (and Russia), as well at the moderate latitudes of Europe and Asia in general, is peculiar. These migrating dragonflies inhabit those regions only in the warm season. In spring they arrive from the main, southern part of the range for reproduction. This arrival may be more a diffusion concerning few individuals than a directed migration of their large numbers. Their much more numerous progeny comprising the summer (temperate) brood directionally migrate to the south in autumn, in swarms following storms. Rich breeding sites of this summer brood should be sought for in 'limans' at the Black and Azov Sea coasts in the western part of Krasnodarskiy Kray, or in water reserves elsewhere in its lowland part, almost not explored in odonatological respect.

\section{Acknowledgements}

The work by the first author was partly supported by the Fund for Science and Innovations (FSI) program № 03242016-0002, the work of the second author was supported by the Russian Foundation for Basic Research (grant № 18-0400725-a) and the Federal Fundamental Scientific Research Program for 2013-2020 (№ AAAA-A16-116121410123-1).

\section{References}

Artobolevskij G.V. 1929. [Les Odonates du Daghestan] // Revue Russe d'Entomologie. Vol.23. P.225-240 [in Russian].

Bartenev A.N. 1921. [Liste des Libellulides du gouvernement de Stavropol] // Revue Russe d'Entomologie. Vol.17. P.144151. [In Russian].

Belle J. 1984. Orthetrum trinacria (Selys) new to the fauna of Spain, with records of three other afrotropical Odonata
Anisoptera // Entomologische Berichten, Amsterdam. Vol.44. P.63-65.

Bernard R., Musial J. 1995. Observations of an abundant occurrence of Hemianax ephippiger (Burmeister, 1839) in Western Poland in 1995 (Odonata: Aeschnidae) // Opuscula zoologica fluminensia. No.138. P.1-9.

Borisov S.N. 2010. [Autumnal migrations of dragonflies (Odonata) in the Chokpak Pass of West Tien-Shan, observed and actual flight measurements] // Evrasiatskii entomologicheskii zhurnal (Euroasian Entomological Journal). Vol.9. No.1. P.7-12. [In Russian].

Borisov S.N. 2011. [Migrant dragonflies in Middle Asia. 1. Anax ephippiger (Burmeister, 1839) (Odonata, Aeshnidae)] // Evrasiatskii entomologicheskii zhurnal (Euroasian Entomological Journal). Vol.10. No.2. P.125-130. [In Russian].

Borisov S.N. 2015. [Migrations of dragonflies (Odonata) in Central Asia: a review. Part 1. Latitudinal migrations] // Evrasiatskii entomologicheskii zhurnal (Euroasian Entomological Journal). Vol.14. No.3. P.241-256. [In Russian].

Corbet Ph.S. 1984. Orientation and reproductive condition of migrating dragonflies (Anisoptera) // Odonatologica. Vol.13. P. 81-88.

Corbet Ph.S. 1999. Dragonflies: Behavior and ecology of Odonata. Colchester: Harley Books. 829 p.

Dumont H.J 2014. Odonata from the Tibesti Mountains and the Ounianga Lakes in Chad, with notes on Hemianax ephippiger accumulating in the desert // Odonatologica. Vol.43. P.1324.

Dumont H.J., Desmet K. 1990. Trans-Sahara and transMediterranean migratory activity of Hemianax ephippiger (Burmeister) in 1988 and 1989 (Anisoptera: Aeshnidae) // Odonatologica. Vol.19. P.181-185.

Faton J.-M. 2003. Avancement de la prospection dans la Drôme et découverte de trois nouvelles espècies dans le département: Coenagtion caerulescens (Fonscolombe, 1838), Gomphus graslini Rambur, 1842 et Hemianax ephippiger (Burmeister, 1839) // Martinia. Vol.19. P.61-64.

Günter A. 2005. Anax ephippiger in Europa - immer Invasionen in eine Sackgasse? // Libellula. Bd.24. S.241-247.

Kalkman, V.J., Monnerat, C. 2015. Anax ephippiger (Burmeister, 1839) // Boudot J.-P., Kalkman V.J. (Eds): Atlas of the European Dragonflies and Damselflies. KNNNV Publishing. Netherlands. P.169-171.

Kosterin O.E., Solovyev V.I. 2017. Odonata found in midsummer 2015 and 2016 at the north-westernmost Black Sea Coast of the Caucasus, with the first record of Cordulegaster picta Selys, 1954 in Russian Federation // International Dragonfly Fund Report. No.107. P.1-43.

Lambret P., Boudot J.-P. 2013. Hemianax ephippiger (Bumeister, 1839) (Odonata, Anisoptera : Aeshnidae): présentation générale // Martinia. Hors-série «Hemianax ephippiger: migration 2011». P.13-27.

Marinov M. 2001. Review of Hemianax ephippiger (Burm.) records from Bulgaria (Anisoptera: Aeshnidae) // Notulae odonatologicae. Vol.5. P.105-106.

May M.L. 2013. A critical overview of progress in studies of migration of dragonflies (Odonata: Anisoptera), with emphasis on North America // Journal of Insect Conservation. Vol.17. No.1. P.1-15.

May M.L., Matthews J.H. 2008. Migration in Odonata: a case study of Anax junius // A. Córdoba-Aguilar (edited): Chapter 6. Dragonflies and Damselflies. Model organisms for ecological and evolutionary research. Oxford University press. P.63-77.

Onishko V.V. 2014. The dragonflies (Odonata) species new for different regions of the Russia // Bulletin of Moscow Society of Naturalists. Biological Series. Vol.19. No.5. P.66-68. [In Russian with English summary].

Pierce A.J. 2017. The first record of Anax ephippiger for Thailand and Southeast Asia (Odonata: Aeshnidae) // Notulae odonatologicae. Vol.8. No.9. P.365-368. 
Russell R.W., May M.L., Soltesz K.L., Fitzpatrick J.W. 1998. Massive swarm migrations of dragonflies (Odonata) in eastern North America // American Midland Naturalist. Vol.140. P.325-342.

Skvortsov V.E. 2010. The Dragonflies of Eastern Europe and Caucasus: an Illustrated Guide. M.: KMK Scientific Press Ltd. 623 p. [Russian and English bilingua].
Vonwil G., Wildermuth H. 1990. Massenentwicklung von Hemianax ephippiger (Burmeister, 1839) in der Schweiz (Odonata:Aeschnidae) // Opuscula zoologica fluminensia. No.51. P.1-11.

Wikelski M., Moskowitz D., Adelman J.S., Cochran J., Wilcove D.S., May M.L. 2006. Simple rules guide dragonfly migration // Biology Letters. Vol.2. P.325-329.

Поступила в редакцию 9.10.2017 